Article

\title{
Antimicrobial PAA/PAH Electrospun Fiber Containing Green Synthesized Zinc Oxide Nanoparticles for Wound Healing
}

\author{
Marina Bandeira ${ }^{1,2, * \mathbb{C}}$, Bor Shin Chee ${ }^{1}(\mathbb{D})$, Rafaele Frassini ${ }^{3}$, Michael Nugent ${ }^{1}\left(\mathbb{D}\right.$, Marcelo Giovanela ${ }^{2}(\mathbb{D}$, \\ Mariana Roesch-Ely ${ }^{3}$, Janaina da Silva Crespo ${ }^{2}$ and Declan M. Devine ${ }^{1, *(D)}$ \\ 1 Materials Research Institute, Athlone Institute of Technology, N37 HD68 Athlone, Ireland; \\ b.schee@research.ait.ie (B.S.C.); mnugent@ait.ie (M.N.) \\ 2 Área do Conhecimento de Ciências Exatas e Engenharias, Universidade de Caxias do Sul, Rua Francisco \\ Getúlio Vargas, 1130, Caxias do Sul 95070-560, RS, Brazil; mgiovan1@ucs.br (M.G.); jscrespo@ucs.br (J.d.S.C.) \\ 3 Instituto de Biotecnologia, Universidade de Caxias do Sul, Rua Francisco Getúlio Vargas, 1130, \\ Caxias do Sul 95070-560, RS, Brazil; rfrassin@ucs.br (R.F.); mrely@ucs.br (M.R.-E.) \\ * Correspondence: m.bandeira@research.ait.ie (M.B.); ddevine@ait.ie (D.M.D.)
}

\section{check for} updates

Citation: Bandeira, M.; Chee, B.S.; Frassini, R.; Nugent, M.; Giovanela, M.; Roesch-Ely, M.; Crespo, J.d.S.; Devine, D.M. Antimicrobial PAA/PAH Electrospun Fiber Containing Green Synthesized Zinc Oxide Nanoparticles for Wound Healing. Materials 2021, 14, 2889. https://doi.org/10.3390/ma14112889

Academic Editor: Roman

Perez Antoñanzas

Received: 28 April 2021

Accepted: 25 May 2021

Published: 27 May 2021

Publisher's Note: MDPI stays neutral with regard to jurisdictional claims in published maps and institutional affiliations.

Copyright: (c) 2021 by the authors. Licensee MDPI, Basel, Switzerland. This article is an open access article distributed under the terms and conditions of the Creative Commons Attribution (CC BY) license (https:// creativecommons.org/licenses/by/ $4.0 /)$.

\begin{abstract}
Wound infections are the main complication when treating skin wounds. This work reports a novel antimicrobial material using green synthesized zinc oxide nanoparticles (ZnONPs) incorporated in polymeric fibers for wound healing purposes. ZnONPs are a promising antimicrobial nanomaterial with high activity against a range of microorganisms, including drug-resistant bacteria. The electrospun fibers were obtained using polyacrylic acid (PAA) and polyallylamine hydrochloride $(\mathrm{PAH})$ and were loaded with ZnONPs green synthesized from Ilex paraguariensis leaves with a spherical shape and $\sim 18 \mathrm{~nm}$ diameter size. The fibers were produced using the electrospinning technique and SEM images showed a uniform morphology with a diameter of $\sim 230 \mathrm{~nm}$. EDS analysis proved a consistent dispersion of $\mathrm{Zn}$ in the fiber mat, however, particle agglomerates with varying sizes were observed. FTIR spectra confirmed the interaction of PAA carboxylic groups with the amine of PAH molecules. Although ZnONPs presented higher antimicrobial activity against S. aureus than E. coli, resazurin viability assay revealed that the PAA/PAH/ZnONPs composite successfully inhibited both bacteria strains growth. Photomicrographs support these results where bacteria clusters were observed only in the control samples. The PAA/PAH/ZnONPs composite developed presents antimicrobial activity and mimics the extracellular matrix morphology of skin tissue, showing potential for wound healing treatments.
\end{abstract}

Keywords: zinc oxide nanoparticles; antimicrobial; electrospinning; polymer fiber; wound healing

\section{Introduction}

Skin wounds are a common condition caused by burns, surgery, skin diseases, traumas, among others, causing physical and psychological stress to the patient. Thus, the development of biomaterials to improve wound closure has been addressed [1,2]. The addition of antimicrobial agents to these biomaterials is also essential, as infections are reported to be the main reason of wound complications [3,4].

Zinc oxide nanoparticles (ZnONPs) are a multifunctional material due to a range of intrinsic properties, such as semiconductivity, UV radiation absorption, low cytotoxicity, and antimicrobial activity against a range of microorganisms $[5,6]$. In addition, this nanomaterial has shown antimicrobial activity against drug-resistant bacteria strains and is considered to be a potential coadjutant in therapy [7]. In the biomedical field, ZnONPs are applied in drug delivery systems, cancer, and tissue regeneration therapies, among others $[8,9]$.

Literature has reported the role of ZnONPs in tissue regeneration [10], where it has been successfully employed for wound healing [11,12]. For instance, Gong et al. [13] and Khalid et al. [14] observed wound healing improvement when applying a polymer material 
loaded with ZnONPs into the wounds. Both studies showed not only the antimicrobial efficacy of ZnONPs but also its importance for faster tissue regeneration and wound closure.

Electrospinning is a low-cost and facile approach to obtain micro and nanofibrous material that is comparable to the extracellular matrices of skin tissue. For instance, scaffolds obtained using this technique have three-dimensional structures formed by thin fibers and presents porosity, flexibility, and mechanical resistance [15]. Several works report the advantages of electrospun fibers for wound healing, such as cell adhesion and proliferation, flexibility, breathability, and facility for drug release [15-17].

Different approaches have been used to incorporate zinc oxide into electrospun fibers varying the polymer or the incorporation of particles. In general, electrospun polymer/zinc oxide fibers were obtained by mixing the particles in the polymer solution before the electrospinning, by adding a zinc precursor in the polymer solution and exposing the electrospun fiber to a calcination process, by incorporating the particles after obtaining the fibers, and by performing an in situ synthesis in the electrospun mat $[18,19]$. In the field of wound healing, electrospun gelatin/ZnONPs were successfully applied as wound dressing [20,21]. Chitosan, polyvinyl alcohol, and sodium alginate are also examples of polymers used to prepare electrospun composites with ZnONPs for tissue engineering [22,23].

Polyacrylic acid (PAA) and polyallylamine hydrochloride (PAH) are weak polyelectrolytes that present negative and positive charges when in solution, respectively. These materials form polymeric complexes due to their opposite charges and their biocompatibility has been reported for a range of applications, like tissue engineering, drug delivery, and implant coatings [24-26]. These polyelectrolytes are water-soluble and require no chemical crosslinking agent as the amino groups of PAH react with the carboxyl groups of the PAA molecules, providing moisture stability and mechanical resistance [25].

The $\mathrm{ZnONPs}$ were synthesized using Ilex paraguariensis leaves via a sustainable process, which is beneficial not only regarding environmental preservation but also to obtain a product with promising low cytotoxicity and side effects, as no hazardous material is used in the process $[27,28]$. Literature reports the synthesis of ZnONPs using different plants [29-34]. For example, ZnONPs obtained with Aloe vera extract and Stevia leaves showed enhanced antibacterial effect against different pathogens [30,34]. Another study used Hibiscus subdarifa leaves and achieved ZnONPs with antidiabetic properties [31]. Here, ZnONPs were biosynthesized using Ilex paraguariensis (IP) leaves extract. This plant is found in South America and is reported to have high concentrations of active compounds, such as chlorogenic acid and caffeine, which are essential for the green synthesis of metal and metal oxide nanoparticles [35-37].

In this work, we report a novel antimicrobial material for wound healing applications by combining the antimicrobial activity of green synthesized ZnONPs with a biocompatible electrospun PAA/PAH polyelectrolyte fiber mat, that resembles the extracellular matrix morphology of the skin tissue.

\section{Materials and Methods}

\subsection{Materials}

Materials used to synthesize the fibers include polyacrylic acid $25 \% w / v$ solution (PAA, MW 345,000, $\left(\mathrm{CH}_{2} \mathrm{CH}\left(\mathrm{CO}_{2} \mathrm{H}\right)-\right)$ n, CAS n. 9003-01-4, Polysciences, Warrington, PA, USA) and polyallylamine hydrochloride (PAH, MW 17,500, $\left(\mathrm{CH}_{2} \mathrm{CH}\left(\mathrm{CH}_{2} \mathrm{NH}_{2} \cdot \mathrm{HCl}\right)\right) \mathrm{n}$, CAS n. 71550-12-4, Sigma Aldrich, St. Louis, MO, USA). The zinc oxide nanoparticles were produced via green synthesis using zinc nitrate hexahydrate $\left(\mathrm{Zn}\left(\mathrm{NO}_{3}\right)_{2} \cdot 6 \mathrm{H}_{2} \mathrm{O}, \mathrm{CAS}\right.$ n. 0196-18-6, Sigma-Aldrich), zinc acetate dihydrate $\left(\left(\mathrm{CH}_{3} \mathrm{COO}\right)_{2} \cdot 2 \mathrm{H}_{2} \mathrm{O}\right.$, CAS n. 5970-45-6, Sigma-Aldrich), and ethanol 99\% $\left(\mathrm{C}_{2} \mathrm{H}_{5} \mathrm{OH}, \mathrm{CAS}\right.$ n. P1000510153081, Didática Artigos para Laboratório Ltd.a.). The plant (Ilex paraguariensis) leaves were collected in the municipality of Caxias do Sul, RS, Brazil, and identified at the Natural Science Museum of University of Caxias do Sul (registration $n^{\circ} 46.334$ ). 
The antimicrobial activity was performed using bacterial strains of Staphylococcus aureus ATCC 25923 (LGC Standards, Middlesex, UK) and Escherichia coli ATCC 35218 (LGC Standards, Middlesex, UK). Bacteria cells were cultured using Mueller Hinton broth (MHB, LAB114-A, Lab M Limited, Lancashire, UK) and resazurin sodium salt $\left(\mathrm{C}_{12} \mathrm{H}_{6} \mathrm{NNaO}_{4}\right.$, CAS n. 62758-13-8, Sigma-Aldrich) was used to evaluate bacteria viability. Glutaraldehyde $50 \% w / v$ solution $\left(\mathrm{C}_{5} \mathrm{H}_{8} \mathrm{O}_{2}\right.$, CAS n. 111-30-8, Alfa Aesar, Ward Hill, MA, USA), phosphate buffer solution (PBS, MDL n. MFCD00131855, Sigma Aldrich), and ethanol 99\% were used to prepare bacteria samples for SEM analysis.

\subsection{Methods}

\subsubsection{Green Synthesis of ZnONPs}

The green synthesized ZnONPs were prepared as described in a previous work [28]. Briefly, to obtain the plant extract, $100 \mathrm{~g} \mathrm{~L}^{-1}$ of IP leaves, previously cleaned, dried (1.5 h at $60{ }^{\circ} \mathrm{C}$ ) and ground in a mill, were heated at $50{ }^{\circ} \mathrm{C}$ and stirred during $20 \mathrm{~min}$ with two different solutions: pure distilled water and a $50 \%(v / v)$ ethanol/water solution (ethanolic extract). The extract was then filtrated and centrifuged for $20 \mathrm{~min}$ at $5000 \mathrm{rpm}$ to remove suspended particles. For the green synthesis, a zinc precursor (zinc nitrate or zinc acetate) in a $\mathrm{Zn}$ (II) concentration of $21.8 \mathrm{~g} \mathrm{~L}^{-1}$ was added in $50 \mathrm{~mL}$ of the IP extract solution previously prepared. The solution was stirred for $1 \mathrm{~h}$ at room temperature and then heated at $70{ }^{\circ} \mathrm{C}$ for $4 \mathrm{~h}$ without stirring. At the end of this procedure, the mixture was thermally treated in a hot air oven at $140^{\circ} \mathrm{C}$ for $1 \mathrm{~h}$ and then calcinated at $400{ }^{\circ} \mathrm{C}$ for $1 \mathrm{~h}$. The final powder was collected for further characterization.

\subsubsection{Preparation of PAA/PAH/ZnO Electrospun Fibers}

A polymer solution was prepared by first mixing $1.6 \mathrm{~mL}$ of PAA with $0.4 \mathrm{~mL}$ of ethanol/water $40 \% v / v$. Then, $0.11 \mathrm{~g}$ of PAH was added to the solution and mixed until homogeneous. The PAA/PAH solution was electrospun using a 0.9 needle and an electrical potential of $10 \mathrm{kV}$. A fixed working distance from the tip of the needle to the stainless-steel plate of $10 \mathrm{~cm}$ was used and the pressure was kept between 0.015 to 0.020 bar. A scheme of the electrospinning process is illustrated in Figure 1. The methodology was adapted from Boas et al. [25] and based on preliminary studies (data not shown).

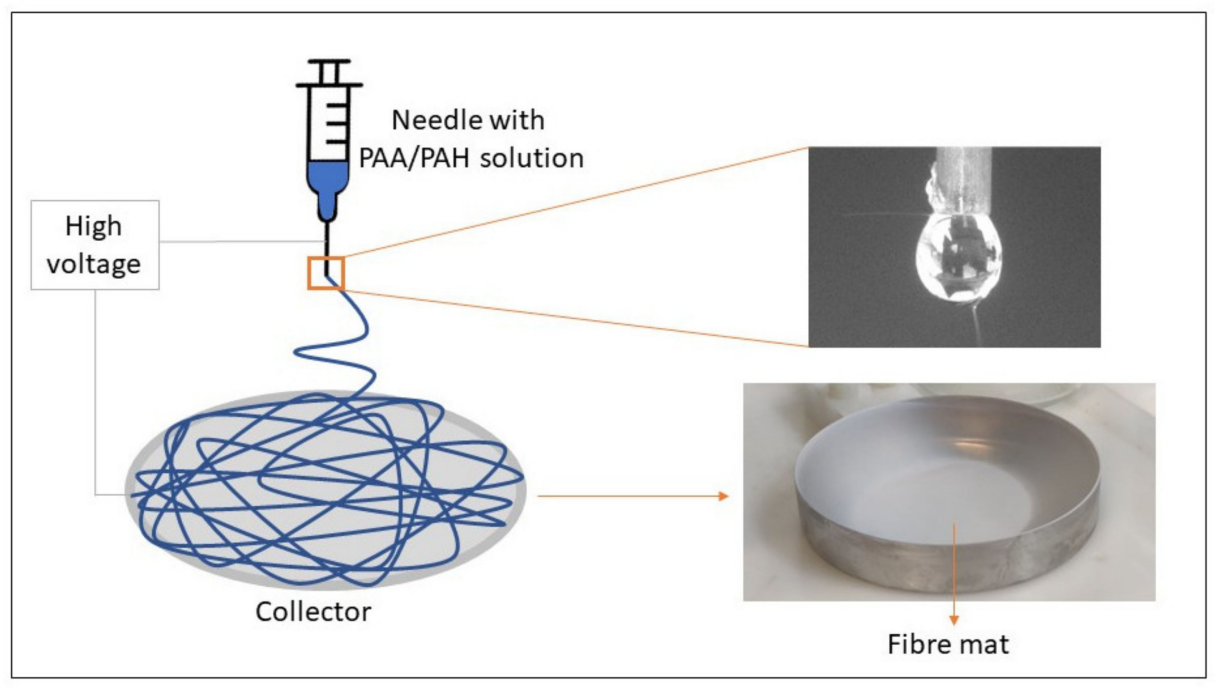

Figure 1. Production of electrospun PAA/PAH fibers.

The fiber mat was then collected from the stainless-steel plate and annealed at $140{ }^{\circ} \mathrm{C}$ for $6 \mathrm{~h}$ for polymer crosslinking. After cooling to room temperature, the electrospun polymer blend was immersed in $20 \mathrm{~mL}$ of a ZnONPs aqueous solution $\left(1 \mathrm{~g} \mathrm{~L}^{-1}\right)$ for $40 \mathrm{~min}$ to allow the absorption of nanoparticles on the fiber mat. The fiber mat was then removed 
from the solution and dried for $2 \mathrm{~h}$ at $37^{\circ} \mathrm{C}$. The ZnONPs solution was prepared by sonicating the solution for $15 \mathrm{~min}$ following a $10 \mathrm{~min}$ of magnetic stirring.

\subsubsection{Field Emission Scanning Electron Microscopy (FESEM) Coupled with Energy} Dispersive Spectroscopy (EDS)

The morphology of the fiber was examined with a field emission scanning electron microscope (FESEM, TESCAN, model MIRA 3, Brno, Czech Republic) equipped with an energy beam of $10 \mathrm{kV}$. Prior to the analysis, the samples were placed in an aluminum stub and were covered with a thin layer of gold by a sputtering method (Denton Vacuum, Desk V, Moorestown, NJ, USA) for $30 \mathrm{~s}$ at $0.13 \mathrm{mbar}$ vacuum to perform the analysis. EDS analysis of $\mathrm{Zn}$ was performed coupled with FESEM using a silicon drift detector (SDD). The mean diameter of the fibers was determined using the Image J (version 1.51j8) software [38], considering the measurements of 15 fibers within a single field of view.

\subsubsection{Zinc Quantification by Inductively Coupled Plasma-Optical Emission} Spectrometry (ICP-OES)

The amount of ZnONPs absorbed in the fibers was quantified on a single sample by means of zinc concentration using ICP-OES (Thermo Scientific 7200-duo, Waltham, MA, USA), according to Standard Methods EPA 3050b (1996) [39].

\subsubsection{Fourier Transform Infrared Spectroscopy (FTIR)}

The interaction of the electrospun PAA and PAH polymers was addressed by FTIR spectroscopy (Perkin Elmer, Waltham, MA, USA). Cast films of pure PAA and PLA were also analyzed for comparison. The spectra were registered in a range of 4000 to $650 \mathrm{~cm}^{-1}$ and a resolution of $1 \mathrm{~cm}^{-1}$ was employed.

\subsubsection{Antimicrobial Assay of $\mathrm{ZnONPs}$}

Staphylococcus aureus ATCC 25923 and Escherichia coli ATCC 25922 were cultured and grown in an exponential phase in $\mathrm{MHB}$ medium at $37^{\circ} \mathrm{C}$. The viability of bacterial cells when exposed to different concentrations of ZnONPs and to the electrospun fiber mats was analyzed in a 96-well plate using the resazurin cell viability assay. Resazurin indicates cell viability by changing from a blue to a pink color upon chemical reduction resulting from aerobic respiration due to cell growth. Thus, the reduction of the dye is proportional to the viable cells present in the solution and the minimum inhibitory concentration is determined when no dye reduction occurs.

Overnight cultures of the two types of bacteria were diluted to a concentration of approximately $1.0 \times 10^{4}$ colony-forming units per milliliter $\left(\mathrm{CFU} \mathrm{mL}{ }^{-1}\right)$. An autoclaved aqueous suspension of $\mathrm{ZnONPs}\left(10 \mathrm{mg} \mathrm{mL}^{-1}\right)$ was diluted in MHB in different concentrations (from 15 to $100 \mu \mathrm{g} \mathrm{mL}^{-1}$ ). Then, $100 \mu \mathrm{L}$ of different $\mathrm{ZnONPs}$ suspension and $5 \mu \mathrm{L}$ of the diluted bacteria were added to each well. Two controls without nanoparticles were also included in each plate: a positive control $(100 \mu \mathrm{L}$ of MHB with $5 \mu \mathrm{L}$ of the diluted bacteria) and a negative control (only $100 \mu \mathrm{L}$ of MHB). After overnight incubation at $37^{\circ} \mathrm{C}, 15 \mu \mathrm{L}$ of resazurin $\left(0.15 \mathrm{mg} \mathrm{mL}^{-1}\right)$ was added to each well and mixed thoroughly for $2 \mathrm{~h}$, and plates were then subjected to absorbance measurement at $600 \mathrm{~nm}$. The test was performed in two individual triplicates.

\subsubsection{Antimicrobial Assay of Electrospun Fibers}

A similar protocol was followed to evaluate the antimicrobial activity of the fiber mats, where $0.5 \mathrm{~cm}^{2}$ of PAA/PAH/ZnONPs and PAA/PAH fibers were incubated in a 96-well plate with $50 \mu \mathrm{L}$ of MHB and $2.5 \mu \mathrm{L}$ of bacteria solution $\left(1 \times 10^{4} \mathrm{CFU} \mathrm{mL}{ }^{-1}\right)$ prepared as previously described. After overnight incubation at $37^{\circ} \mathrm{C}, 7.5 \mu \mathrm{L}$ of resazurin was added to each well and incubated for a further $2 \mathrm{~h}$. Then, the fibers were removed, and the absorbance was measured at $600 \mathrm{~nm}$. A positive control $(50 \mu \mathrm{L}$ of MHB and $2.5 \mu \mathrm{L}$ of bacteria solution) and negative control ( $50 \mu \mathrm{L}$ of $\mathrm{MHB})$ were included in each plate and the tests were performed in two individual triplicates. 
Microbial adhesion to the fibers was evaluated using FESEM analysis. For this, the antimicrobial test was performed as described above, but without the addition of resazurin. Thus, after overnight incubation, the media was removed from the wells and bacteria cells were fixed with $3 \%$ glutaraldehyde solution in PBS $(v / v)$ for $15 \mathrm{~min}$ at $4{ }^{\circ} \mathrm{C}$, following a sequence of dehydration with $30,50,70,90$, and $100 \%(v / v)$ ethanol aqueous solutions for $10 \mathrm{~min}$. The fiber mats were then kept in a desiccator until the analysis was performed. The samples were gold-coated in sputtering equipment (Baltec model SCD 005, Canonsburg, PA, USA) for $110 \mathrm{~s}$ at $0.1 \mathrm{mbar}$ prior to the FESEM analysis in high vacuum mode with a maximum beam voltage of $9 \mathrm{kV}$ and back-scattered electron mode.

\section{Results and Discussion}

\subsection{ZnONPs Green Synthesized}

The ZnONPs were synthesized using Ilex paraguariensis leaves extract using a green synthesis approach. The synthesis was evaluated according to the zinc source and plant extract solvent, and the ZnONPs were characterized according to their morphology, size, and cytotoxicity. These results were carefully discussed in a previous work [28]. Briefly, the sample produced with zinc nitrate and ethanolic plant extract resulted in the most uniform particle with a spherical shape and a diameter of $18 \pm 5 \mathrm{~nm}$. This sample also presented the least cytotoxicity against L929 mouse fibroblast cells and was chosen to be applied in the electrospun fiber here developed.

\subsection{Characterization of Electrospun Fibers}

The morphology and size of the polymer electrospun fibers were examined using SEM analysis as shown in Figure 2. The thermal treatment of the fibers (Figure 2A). resulted in an increase in the uniformity of the fibers, resulting in an average diameter of $\sim 230 \mathrm{~nm}$, while the non-thermal treated sample (Figure $2 \mathrm{~B}$ ) presented irregular morphology showing a mix of beads with a diameter up to $4 \mu \mathrm{m}$ and fibers with a diameter of $\sim 240 \mathrm{~nm}$. PAA and $\mathrm{PAH}$ are polyelectrolytes that form electrostatic complexes due to the opposite charges of carboxylate $\left(-\mathrm{COO}^{-}\right)$and amine $\left(-\mathrm{NH}_{3}{ }^{+}\right)$groups present in the PAA and PAH molecules, respectively [25]. The thermal treatment results in the crosslinking of the polyelectrolytes through these carboxylate and amine groups, which improves the uniformity of the fibers and moisture stability [25]. The morphology of the electrospun scaffold is also found to be suitable for wound dressing as it mimics the extracellular matrix of skin tissue, having a fibrous three-dimensional structure, which provides mechanical support for cell attachment and growth and benefits wound healing [40,41].

Figure 2C. presents the morphology of the fiber after the incorporation of ZnONPs with an elemental analysis of $\mathrm{Zn}$ identified by EDS analysis. the incorporation process of ZnONPs did not affect the morphology and size of the fiber mat, as it maintained its characteristics. The green synthesized ZnONPs were characterized in a preview work and have a spherical shape and an average size of $18 \mathrm{~nm}$ [28].

However, even though EDS analysis shows a homogeneous dispersion of ZnONPs in the fiber mat, different sizes of agglomerates of nanoparticles were formed. This result might be related to the high concentration of the ZnONPs solution. Considering that it is now known that the fibers can absorb a considerable amount of ZnONPs, more diluted nanoparticle solutions should be used in an attempt to decrease the particle agglomerates. Different studies have produced electrospun fiber containing zinc oxide but usually by incorporating the ZnONPs into the polymer solution, which resulted in a more uniform dispersion of nanoparticles without particle agglomeration [22,23]. Nonetheless, this approach was not possible in this study due to the non-homogeneous solution formed when mixing the polyelectrolytes with the ZnONPs.

The concentration of zinc oxide incorporated in the fibers was measured using ICPOES. The analysis resulted in a concentration of $9.01 \mathrm{wt} \%$ of $\mathrm{Zn}$ (II). Considering that $\mathrm{ZnO}$ is constituted of $80.3 \%$ of $\mathrm{Zn}(\mathrm{II})$, the amount of $\mathrm{ZnONPs}$ in the fiber mat is $11.2 \mathrm{wt} \%$. The fiber mats presented a thickness of $30 \pm 3 \mu \mathrm{m}$ and a grammage of $0.83 \pm 0.20 \mathrm{mg} \mathrm{cm}$. 
There was no significant difference between the fibers with and without ZnONPs in these aspects. Therefore, the concentration of $\mathrm{ZnONPs}$ per area of the fiber mat is approximately $0.09 \mathrm{mg} \mathrm{cm}^{2}$.
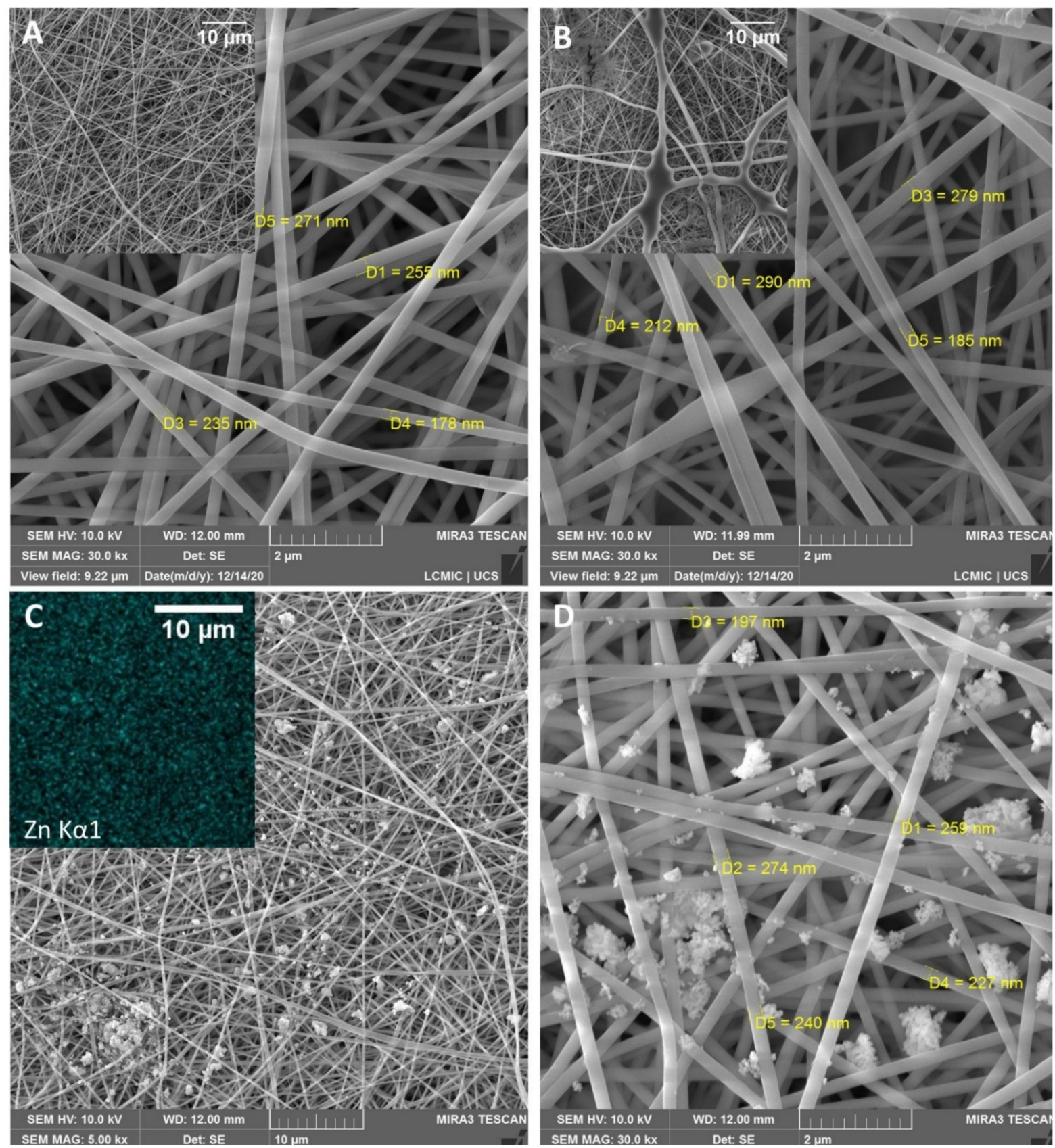

Figure 2. Photomicrograph of (A) PAA/PAH fiber mat thermally treated, (B) PAA/PAH fiber without thermal treatment, (C) PAA/PAH fiber containing ZnONPs and EDS analysis of elemental zinc and, (D) Amplification of PAA/PAH fibers containing ZnONPs.

\subsection{Fourier Transform Infrared Spectroscopy (FTIR)}

FTIR spectra of the different fiber mats in comparison to the cast film of pure PAA and PAH are shown in Figure 3. The main peaks are reported and assigned to their respective groups in Table 1. Peaks 1450 and $1410 \mathrm{~cm}^{-1}$ were seen in every sample and are assigned to $\mathrm{C}-\mathrm{H}$ vibration of the carbon chain of the polymers. PAH shows the characteristic peaks of primary amines (3400 and $1600 \mathrm{~cm}^{-1}$ ) while the PAA presents a strong peak at $1695 \mathrm{~cm}^{-1}$ 
related to the $\mathrm{C}=\mathrm{O}$ stretching of carboxylic acid [25]. The peak at $1260 \mathrm{~cm}^{-1}$ is also related to the carboxylic acid group but it is associated with the $\mathrm{C}-\mathrm{O}$ stretching and is seen in both PAA and PAA/PAH nt samples. These peaks related to the carboxylic acid groups are also presented in both non-thermal treated and thermally treated PAA/PAH samples. However, it is absent in the PAA/PAH/ZnONPs spectrum. The peaks between 1580 and $1550 \mathrm{~cm}^{-1}$ in the fiber samples are related to the amide groups, which are formed by the reaction of the carboxylic acid with the amine groups during polymer cross-linking [42].

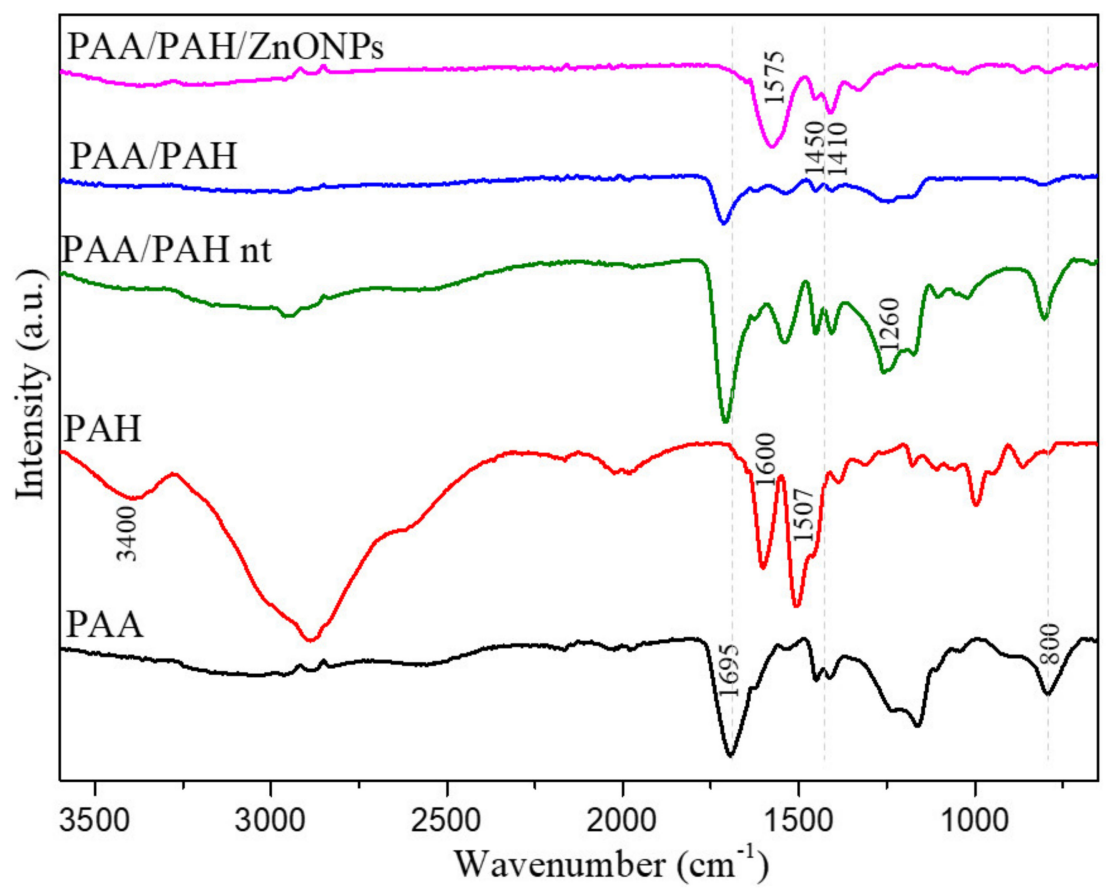

Figure 3. FTIR spectra of fiber mats and PAA and PLA cast films.

Table 1. Description of FTIR peaks.

\begin{tabular}{cc}
\hline Wavenumber $\left(\mathbf{c m}^{-\mathbf{1}}\right)$ & Group \\
\hline 3400 & N-H stretching (amine) \\
1695 & C=O stretching (carboxylic acid) \\
1600 & N-H bending (amine) \\
1575 & -NH bending (amide) \\
1450,1410 & C-H bending \\
1260 & C-O stretching \\
\hline
\end{tabular}

\subsection{Antimicrobial Activity of $\mathrm{ZnONPS}$}

An antibacterial assay was performed to evaluate the antimicrobial potential of the ZnONPs green synthesized in different concentrations $\left(15\right.$ to $\left.55 \mu \mathrm{g} \mathrm{mL}^{-1}\right)$. The results are shown in Figure 4. Overall, ZnONPs showed antimicrobial activity to both bacteria strains. However, a higher antimicrobial activity was observed in Gram-positive (S. aureus) compared to Gram-negative (E. coli) bacteria. The minimum inhibitory concentration (MIC) is determined as the lower concentration where no resazurin reduction occurred. Therefore, the MIC of ZnONPs for the Gram-positive S. aureus was $35 \mu \mathrm{g} \mathrm{mL}^{-1}$, while the Gramnegative $E$. coli showed higher resistance with $70 \%$ viability in the highest concentration tested $\left(100 \mu \mathrm{g} \mathrm{mL}{ }^{-1}\right)$. 


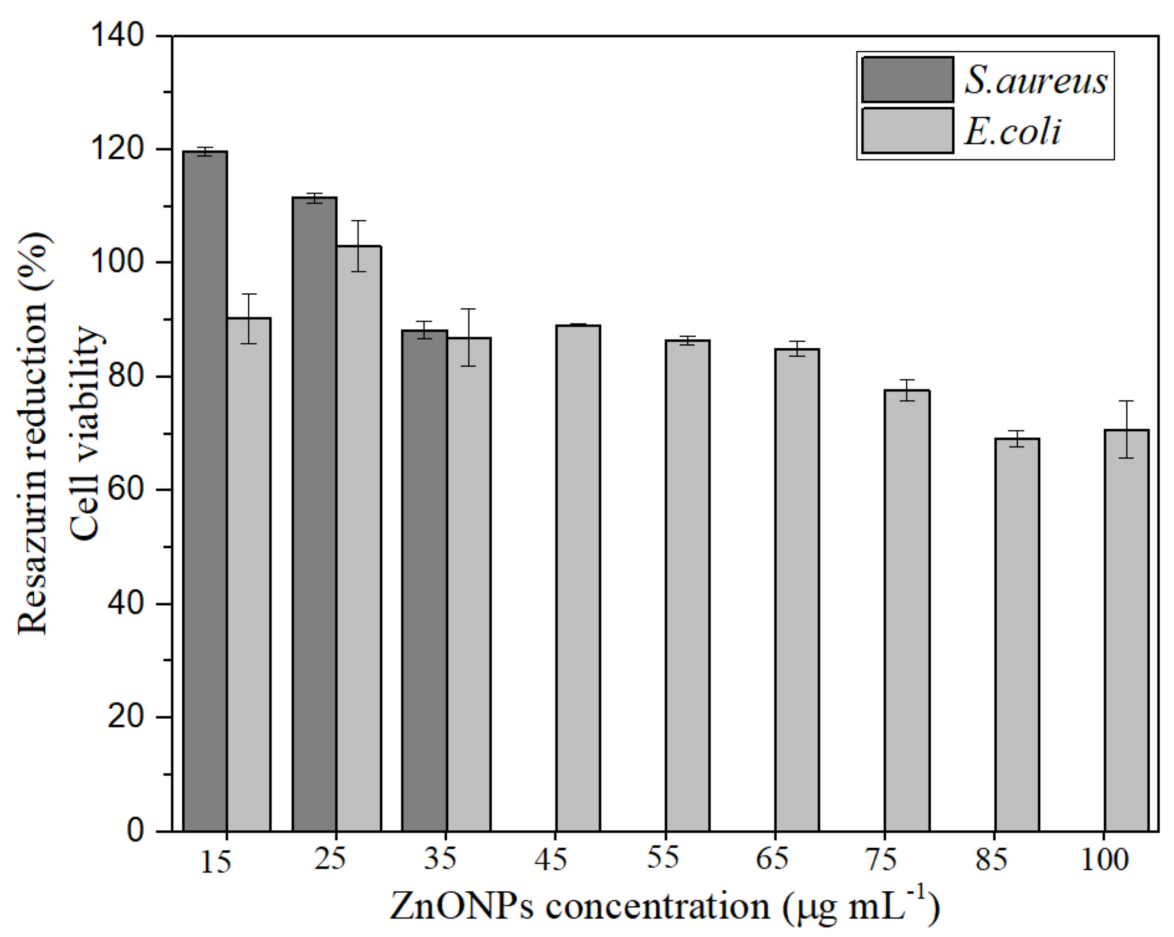

Figure 4. Antimicrobial activity of green synthesized ZnONPs shows higher bacteria inhibition against $S$. aureus strain in comparison to E. coli strain.

Previous works have also reported higher toxicity of ZnONPs to Gram-positive bacteria than Gram-negative [43-46]. This feature is related to the different cell structures of Gram-positive and Gram-negative bacteria. The antimicrobial activity mechanism of metal and metal oxide nanoparticles involves membrane damage, nanoparticle internalization, metal ions, and reactive oxygen species (ROS) that affect cell metabolism [47,48]. For instance, Gram-positive cells have a thicker peptidoglycan layer than Gram-negative bacteria. Nonetheless, Gram-negative have an outer membrane surrounded by lipids and proteins, which can result in higher resistance to nanoparticle and metal ions penetration into the cell. Moreover, Gram-positive bacteria have a more negatively charged surface, which facilitates the attraction of positive ions, such as $\mathrm{Zn}(\mathrm{II})$ ions that can be released from the dissolution of ZnONPs [49,50].

\subsection{Antimicrobial Activity of Electrospun Fibers}

The antimicrobial activity of the electrospun fibers is presented in Figure 5. The PAA/PAH fiber decreased the S. aureus cell viability to around $40 \%$. Conversely, the E. coli showed higher resistance to the fiber mat with only a $10 \%$ drop of cell viability in comparison to the positive control. The PAA/PAH/ZnONPs fiber composite was efficient to inhibit both bacteria strains as no dye reduction was observed, confirming the role of ZnONPs in the antimicrobial efficacy of the electrospun fibers. This result can also be observed in the well-plate pictures in Figure 5, where the replicates in row 1 did not reduce the resazurin dye, maintaining the blue color, while the PAA/PAH in row 2 presented some degree of dye reduction in comparison to the row 3 , which represents the maximum cell viability. Row 4 showed no dye reduction, as no bacteria were incubated in these wells (negative control). 


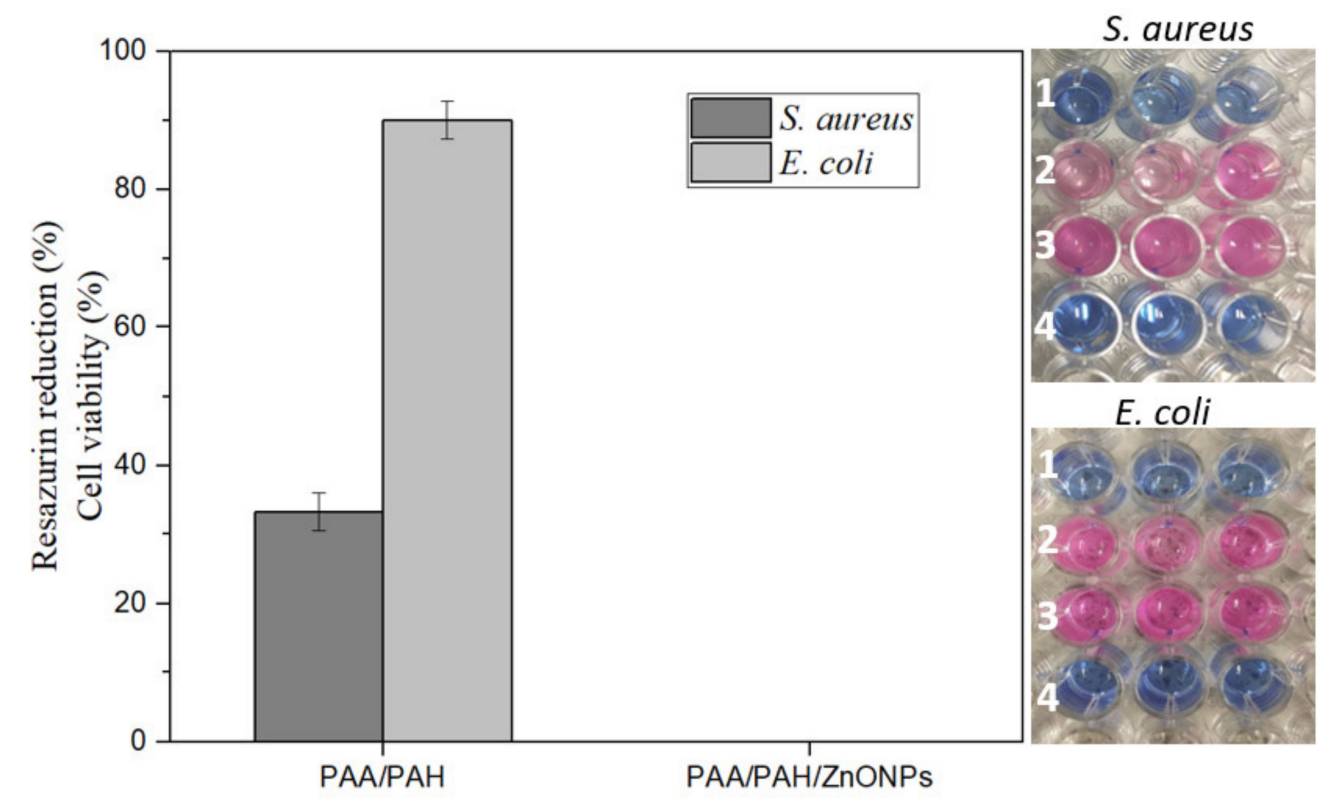

Figure 5. Resazurin antimicrobial assay demonstrates total bacteria growth inhibition for the electrospun fiber containing ZnONPs in comparison to the PAA/PAH fiber mat (1) PAA/PAH/ZnO, (2) PAA/PAH fiber, (3) positive control and, (4) negative control.

The final concentration of $\mathrm{ZnONPs}$ when testing the PAA/PAH/ZnONPs sample was found to be $900 \mu \mathrm{g} \mathrm{mL}^{-1}$, once a fiber mat of $0.5 \mathrm{~cm}^{2}$ (which contains $0.045 \mathrm{mg}$ of ZnONPs) was placed in $0.05 \mathrm{~mL}$ of MHB in each well. Therefore, the antimicrobial activity of the $\mathrm{PAA} / \mathrm{PAH} / \mathrm{ZnONPs}$ was expected as it surpassed the MIC for both bacteria strains. Even though the MIC for E. coli was not observed up to a concentration of $100 \mu \mathrm{g} \mathrm{mL} \mathrm{L}^{-1}$, total cell growth inhibition indicates that the MIC was achieved when using the $900 \mu \mathrm{g} \mathrm{mL}^{-1}$ concentration.

FESEM photomicrographs of the fiber after performing the antimicrobial assay are presented in Figure 6. This analysis corroborates with the resazurin assay as no bacteria growth was observed in the PAA/PAH/ZnONPs fibers for both E. coli and S. aureus strains. In addition, S. aureus formed isolated colony clusters in the control sample (PAA/PAH) while the E. coli covered nearly the whole surface of the scaffold forming a biofilm, confirming the results observed in the resazurin dye assay.

The FESEM photomicrographs also show that $S$. aureus clusters are formed by spherical cells and are presented only on the surface of the fibers (Figure 6B,C). Conversely, E. coli cells are rod in shape and are attached to the fibers, using the structure of the material to support their growth, as shown in Figure 6E,F. 


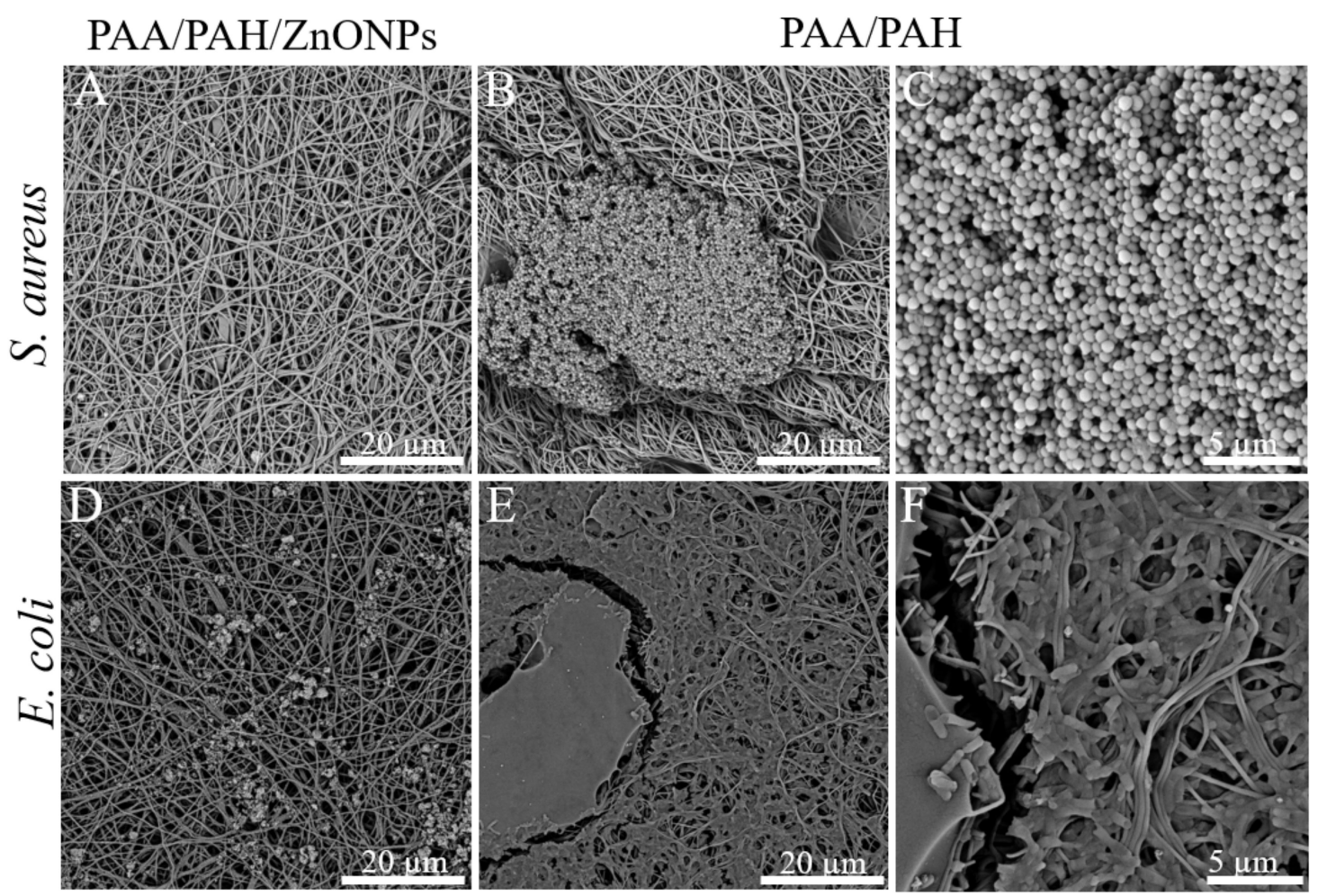

Figure 6. SEM photomicrographs indicate that the presence of ZnONPs inhibits bacteria growth (A) PAA/PAH/ZnONPs sample after $24 \mathrm{~h}$ incubation with S. aureus, (B) PAA/PAH sample after $24 \mathrm{~h}$ incubation with S. aureus, (C) amplification of image B to highlight the $S$. aureus bacteria cluster morphology, (D) PAA/PAH/ZnONPs sample after $24 \mathrm{~h}$ incubation with E. coli, (E) PAA/PAH sample after $24 \mathrm{~h}$ incubation with E. coli, and (F) amplification of image C to highlight the $E$. coli bacteria morphology and attachment to the fibers.

\section{Conclusions}

Polymer fibers were successfully prepared using the electrospinning technique and posteriorly loaded with green synthesized ZnONPs with spherical shape and a diameter of $\sim 18 \mathrm{~nm}$. The fiber scaffold was formed by uniform PAA/PAH fibers and presented an even distribution of $\mathrm{ZnONPs}$. However, some agglomerates of the nanomaterials were observed.

The electrospun fibers showed a similar morphology to the extracellular matrix of skin tissue and the addition of ZnONPs inhibited both Gram-negative and Gram-positive bacteria strains. These features display the potential of this novel material to be used for wound dressings aiming for faster wound healing and infection prevention. In future work, the particle agglomeration needs to be improved and the biocompatibility of the material must be addressed to confirm the application for tissue regeneration.

Author Contributions: Conceptualization, M.B., M.R.-E., J.d.S.C. and D.M.D.; methodology, M.B., B.S.C., M.N., M.G. and R.F.; validation, M.B., B.S.C. and R.F.; formal analysis, M.B., B.S.C. and R.F.; resources, J.d.S.C., M.R.-E. and D.M.D.; writing—original draft preparation, M.B.; writing-review and editing, M.B., M.G., J.d.S.C., M.R.-E. and D.M.D.; supervision, M.R.-E., J.d.S.C. and D.M.D.; project administration, M.R.-E., J.d.S.C. and D.M.D.; funding acquisition, J.d.S.C. and D.M.D. All authors have read and agreed to the published version of the manuscript.

Funding: This research was funded by a scholarship granted by CAPES (PDSE-88881.187620/2018-01 and 88887.153309/2017-00) and CNPq (426731;2018-2).

Institutional Review Board Statement: Not applicable.

Informed Consent Statement: Not applicable. 
Data Availability Statement: All data generated or analyzed during this study are included in the article.

Acknowledgments: The authors acknowledge the guidance and support received from the research institute at the Athlone Institute of Technology and the University of Caxias do Sul.

Conflicts of Interest: The authors declare no conflict of interest.

\section{References}

1. Shpichka, A.; Butnaru, D.; Bezrukov, E.A.; Sukhanov, R.B.; Atala, A.; Burdukovskii, V.; Zhang, Y.; Timashev, P. Skin tissue regeneration for burn injury. Stem Cell Res. Ther. 2019, 10, 1-16. [CrossRef]

2. Wang, S.; Xiong, Y.; Chen, J.; Ghanem, A.; Wang, Y.; Yang, J.; Sun, B. Three Dimensional Printing Bilayer Membrane Scaffold Promotes Wound Healing. Front. Bioeng. Biotechnol. 2019, 7, 1-11. [CrossRef] [PubMed]

3. Tottoli, E.M.; Dorati, R.; Genta, I.; Chiesa, E.; Pisani, S.; Conti, B. Skin wound healing process and new emerging technologies for skin wound care and regeneration. Pharmaceutics 2020, 12, 735. [CrossRef] [PubMed]

4. Qu, J.; Zhao, X.; Liang, Y.; Zhang, T.; Ma, P.X.; Guo, B. Antibacterial adhesive injectable hydrogels with rapid self-healing, extensibility and compressibility as wound dressing for joints skin wound healing. Biomaterials 2018, 183, 185-199. [CrossRef]

5. Kaushik, M.; Niranjan, R.; Thangam, R.; Madhan, B.; Pandiyarasan, V.; Ramachandran, C.; Oh, D.H.; Venkatasubbu, G.D. Investigations on the antimicrobial activity and wound healing potential of ZnO nanoparticles. Appl. Surf. Sci. 2019, 479, 1169-1177. [CrossRef]

6. Wojnarowicz, J.; Chudoba, T.; Lojkowski, W. A review of microwave synthesis of zinc oxide nanomaterials: Reactants, process parameters and morphoslogies. Nanomaterials 2020, 10, 1086. [CrossRef] [PubMed]

7. Tiwari, V.; Mishra, N.; Gadani, K.; Solanki, P.S.; Shah, N.A.; Tiwari, M. Mechanism of anti-bacterial activity of zinc oxide nanoparticle against Carbapenem-Resistant Acinetobacter baumannii. Front. Microbiol. 2018, 9, 1-10. [CrossRef] [PubMed]

8. Mishra, P.K.; Mishra, H.; Ekielski, A.; Talegaonkar, S.; Vaidya, B. Zinc oxide nanoparticles: A promising nanomaterial for biomedical applications. Drug Discov. Today 2017, 22, 1825-1834. [CrossRef]

9. Mirzaei, H.; Darroudi, M. Zinc oxide nanoparticles: Biological synthesis and biomedical applications. Ceram. Int. 2016, 43, 907-914. [CrossRef]

10. Laurenti, M.; Cauda, V. ZnO nanostructures for tissue engineering applications. Nanomaterials 2017, 7, 374. [CrossRef]

11. Batool, M.; Khurshid, S.; Qureshi, Z.; Daoush, W.M. Adsorption, antimicrobial and wound healing activities of biosynthesised zinc oxide nanoparticles. Chem. Pap. 2021, 75, 893-907. [CrossRef]

12. Yuvaraja, G.; Pathak, J.L.; Zhang, W.; Zhang, Y.; Jiao, X. Antibacterial and wound healing properties of chitosan/poly(vinyl alcohol)/zinc oxide beads (CS/PVA/ZnO). Int. J. Biol. Macromol. 2017, 103, 234-241. [CrossRef]

13. Gong, C.P.; Luo, Y.; Pan, Y.Y. Novel synthesized zinc oxide nanoparticles loaded alginate-chitosan biofilm to enhanced wound site activity and anti-septic abilities for the management of complicated abdominal wound dehiscence. J. Photochem. Photobiol. $B$ Biol. 2019, 192, 124-130. [CrossRef] [PubMed]

14. Khalid, A.; Khan, R.; Ul-Islam, M.; Khan, T.; Wahid, F. Bacterial cellulose-zinc oxide nanocomposites as a novel dressing system for burn wounds. Carbohydr. Polym. 2017, 164, 214-221. [CrossRef] [PubMed]

15. Parham, S.; Kharazi, A.Z.; Bakhsheshi-Rad, H.R.; Ghayour, H.; Ismail, A.F.; Nur, H.; Berto, F. Electrospun Nano-fibers for biomedical and tissue engineering applications: A comprehensive review. Materials 2020, 13, 2153. [CrossRef]

16. Azimi, B.; Maleki, H.; Zavagna, L.; Gustavo, J.; Ossa, D.; Linari, S.; Lazzeri, A.; Danti, S. Bio-Based Electrospun Fibers for Wound Healing. J. Funct. Biomater. 2020, 11, 67. [CrossRef]

17. Keirouz, A.; Zakharova, M.; Kwon, J.; Robert, C.; Koutsos, V.; Callanan, A.; Chen, X.; Fortunato, G.; Radacsi, N. High-throughput production of silk fibroin-based electrospun fibers as biomaterial for skin tissue engineering applications. Mater. Sci. Eng. C 2020, 112. [CrossRef]

18. Blachowicz, T.; Ehrmann, A. Recent developments in electrospun ZnO nanofibers: A short review. J. Eng. Fiber. Fabr. 2020, 15, 1-6. [CrossRef]

19. Ferrone, E.; Araneo, R.; Notargiacomo, A.; Pea, M.; Rinaldi, A. ZnO nanostructures and electrospun ZnO-polymeric hybrid nanomaterials in biomedical, health, and sustainability applications. Nanomaterials 2019, 9, 1449. [CrossRef]

20. Chhabra, H.; Deshpande, R.; Kanitkar, M.; Jaiswal, A.; Kale, V.P.; Bellare, J.R. A nano zinc oxide doped electrospun scaffold improves wound healing in a rodent model. RSC Adv. 2016, 6, 1428-1439. [CrossRef]

21. Chen, Y.; Lu, W.; Guo, Y.; Zhu, Y.; Song, Y. Electrospun gelatin fibers surface loaded ZnO particles as a potential biodegradable antibacterial wound dressing. Nanomaterials 2019, 9, 525. [CrossRef] [PubMed]

22. Ahmed, R.; Tariq, M.; Ali, I.; Asghar, R.; Noorunnisa Khanam, P.; Augustine, R.; Hasan, A. Novel electrospun chitosan/polyvinyl alcohol/zinc oxide nanofibrous mats with antibacterial and antioxidant properties for diabetic wound healing. Int. J. Biol. Macromol. 2018, 120, 385-393. [CrossRef] [PubMed]

23. Shalumon, K.T.; Anulekha, K.H.; Nair, S.V.; Nair, S.V.; Chennazhi, K.P.; Jayakumar, R. Sodium alginate/poly(vinyl alcohol)/nano $\mathrm{ZnO}$ composite nanofibers for antibacterial wound dressings. Int. J. Biol. Macromol. 2011, 49, 247-254. [CrossRef] 
24. Pallotta, A.; Parent, M.; Clarot, I.; Luo, M.; Borr, V.; Dan, P.; Decot, V.; Menu, P.; Safar, R.; Joubert, O.; et al. Blood Compatibility of Multilayered Polyelectrolyte Films Containing Immobilized Gold Nanoparticles. Part. Part. Syst. Charact. 2017, 34, 1-8. [CrossRef]

25. Boas, M.; Gradys, A.; Vasilyev, G.; Burman, M.; Zussman, E. Electrospinning polyelectrolyte complexes: PH-responsive fibers. Soft Matter 2015, 11, 1739-1747. [CrossRef]

26. Pattabhi, S.R.; Lehaf, A.M.; Schlenoff, J.B.; Keller, T.C.S. Human mesenchymal stem cell osteoblast differentiation, ECM deposition, and biomineralization on PAH/PAA polyelectrolyte multilayers. J. Biomed. Mater. Res. Part A 2015, 103, 1818-1827. [CrossRef]

27. Ahmed, S.; Ali, S.; Ikram, S. A review on biogenic synthesis of ZnO nanoparticles using plant extracts and microbes: A prospect towards green chemistry. J. Photochem. Photobiol. B Biol. 2017, 166, 272-284. [CrossRef] [PubMed]

28. Bandeira, M.; Possan, A.L.; Pavin, S.S.; Raota, C.S.; Vebber, M.C.; Giovanela, M.; Roesch-Ely, M.; Devine, D.M.; Crespo, J.S. Mechanism of formation, characterization and cytotoxicity of green synthesized zinc oxide nanoparticles obtained from Ilex paraguariensis leaves extract. Nano Struct. Nano Objects 2020, 24, 100532. [CrossRef]

29. Nava, O.J.; Luque, P.A.; Gómez-Gutiérrez, C.M.; Vilchis-Nestor, A.R.; Castro-Beltrán, A.; Mota-González, M.L.; Olivas, A. Influence of Camellia sinensis extract on Zinc Oxide nanoparticle green synthesis. J. Mol. Struct. 2017, 1134, 121-125. [CrossRef]

30. Gunalan, S.; Sivaraj, R.; Rajendran, V. Green synthesized ZnO nanoparticles against bacterial and fungal pathogens. Prog. Nat. Sci. Mater. Int. 2012, 22, 693-700. [CrossRef]

31. Bala, N.; Saha, S.; Chakraborty, M.; Maiti, M.; Das, S.; Basu, R.; Nandy, P. Green synthesis of zinc oxide nanoparticles using Hibiscus subdariffa leaf extract: Effect of temperature on synthesis, anti-bacterial activity and anti-diabetic activity. RSC Adv. 2015, 5, 4993-5003. [CrossRef]

32. Matinise, N.; Fuku, X.G.; Kaviyarasu, K.; Mayedwa, N.; Maaza, M. ZnO nanoparticles via Moringa oleifera green synthesis: Physical properties \& mechanism of formation. Appl. Surf. Sci. 2017, 406, 339-347. [CrossRef]

33. Siripireddy, B.; Mandal, B.K. Facile green synthesis of zinc oxide nanoparticles by Eucalyptus globulus and their photocatalytic and antioxidant activity. Adv. Powder Technol. 2017, 28, 785-797. [CrossRef]

34. Khatami, M.; Alijani, H.Q.; Heli, H.; Sharifi, I. Rectangular shaped zinc oxide nanoparticles: Green synthesis by Stevia and its biomedical efficiency. Ceram. Int. 2018, 44, 15596-15602. [CrossRef]

35. Riachi, L.G.; De Maria, C.A.B. Yerba mate: An overview of physiological effects in humans. J. Funct. Foods 2017, 38, 308-320. [CrossRef]

36. Kharissova, O.V.; Dias, H.V.R.; Kharisov, B.I.; Pérez, B.O.; Pérez, V.M.J. The greener synthesis of nanoparticles. Trends Biotechnol. 2013, 31, 240-248. [CrossRef]

37. Kuppusamy, P.; Yusoff, M.M.; Maniam, G.P.; Govindan, N. Biosynthesis of metallic nanoparticles using plant derivatives and their new avenues in pharmacological applications-An updated report. Saudi Pharm. J. 2016, 24, 473-484. [CrossRef] [PubMed]

38. Rueden, C.T.; Schindelin, J.; Hiner, M.C.; DeZonia, B.E.; Walter, A.E.; Arena, E.T.; Eliceiri, K.W. ImageJ2: ImageJ for the next generation of scientific image data. BMC Bioinform. 2017, 18, 1-26. [CrossRef] [PubMed]

39. U.S. EPA. Method 3050B: Acid Digestion of Sediments, Sludges, and Soils; U.S. EPA: Washington, DC, USA, 1996.

40. Jun, I.; Han, H.S.; Edwards, J.R.; Jeon, H. Electrospun fibrous scaffolds for tissue engineering: Viewpoints on architecture and fabrication. Int. J. Mol. Sci. 2018, 19, 745. [CrossRef]

41. Nemati, S.; Kim, S.-j.; Shin, Y.M.; Shin, H. Current progress in application of polymeric nanofibers to tissue engineering. Nano Converg. 2019, 6, 1-16. [CrossRef]

42. Esfahani, A.R.; Zhang, Z.; Sip, Y.Y.L.; Zhai, L.; Sadamani, A.H.M.A. Removal of heavy metals from water using electrospun polyelectrolyte complex fiber mats. J. Water Process Eng. 2020, 37. [CrossRef]

43. Sirelkhatim, A.; Mahmud, S.; Seeni, A.; Kaus, N.H.M.; Ann, L.C.; Bakhori, S.K.M.; Hasan, H.; Mohamad, D. Review on zinc oxide nanoparticles: Antibacterial activity and toxicity mechanism. Nano-Micro Lett. 2015, 7, 219-242. [CrossRef]

44. Emami-Karvani, Z.; Chehrazi, P. Antibacterial activity of ZnO nanoparticle on Gram-positive and Gram-negative bacteria. Afr. J. Microbiol. Res. 2011, 5, 1368-1373. [CrossRef]

45. Premanathan, M.; Karthikeyan, K.; Jeyasubramanian, K.; Manivannan, G. Selective toxicity of ZnO nanoparticles toward Grampositive bacteria and cancer cells by apoptosis through lipid peroxidation. Nanomed. Nanotechnol. Biol. Med. 2011, 7, 184-192. [CrossRef] [PubMed]

46. Lallo da Silva, B.; Caetano, B.L.; Chiari-Andréo, B.G.; Pietro, R.C.L.R.; Chiavacci, L.A. Increased antibacterial activity of ZnO nanoparticles: Influence of size and surface modification. Colloids Surf. B Biointerfaces 2019, 177, 440-447. [CrossRef] [PubMed]

47. Nava, O.J.; Soto-Robles, C.A.; Gómez-Gutiérrez, C.M.; Vilchis-Nestor, A.R.; Castro-Beltrán, A.; Olivas, A.; Luque, P.A. Fruit peel extract mediated green synthesis of zinc oxide nanoparticles. J. Mol. Struct. 2017, 1147, 1-6. [CrossRef]

48. Sangeetha, G.; Rajeshwari, S.; Venckatesh, R. Green synthesis of zinc oxide nanoparticles by aloe barbadensis miller leaf extract: Structure and optical properties. Mater. Res. Bull. 2011, 46, 2560-2566. [CrossRef]

49. Esmailzadeh, H.; Sangpour, P.; Shahraz, F.; Hejazi, J.; Khaksar, R. Effect of nanocomposite packaging containing ZnO on growth of Bacillus subtilis and Enterobacter aerogenes. Mater. Sci. Eng. C 2016, 58, 1058-1063. [CrossRef]

50. Dimapilis, E.A.S.; Hsu, C.S.; Mendoza, R.M.O.; Lu, M.C. Zinc oxide nanoparticles for water disinfection. Sustain. Environ. Res. 2018, 28, 47-56. [CrossRef] 